IBIMA Publishing

Journal of e-health Management

https://ibimapublishing.com/articles/JEHM/2022/489760/

Vol. 2022 (2022), Article ID 489760, 9 pages, ISSN: 2165-9478

DOI: $10.5171 / 2022.489760$

Research Article

\title{
Romania's Health Management In The Context of Covid-19
}

\author{
Ioana A. PADURARIU \\ The Bucharest University of Economic Studies, Bucharest, Romania \\ padurariu_ioana24@yahoo.com
}

Received date:5 March 2021; Accepted date: 20 July 2021; published date: 28 January 2022

Academic Editor: Ștefan Cătălin Popa

Copyright (C 2022. Ioana A. PADURARIU. Distributed under Creative Commons Attribution 4.0 International CC-BY 4.0

\begin{abstract}
For helth system and community, COVID-19 pandemic has created an extraordinary environment in a negative way. Under such circumstances, it seems appropriate that this paper work focus on how the pandemic might impact upon health system and also offer reflections on the past year, being an unique opportunity to investigate an unpreced event. It required a fast and prompt response despite the fact that the coronavirus pandemic was a widespread event and its eruption being alarmingly fast that governments, with some exceptions, had no benchmark or previous experience to rely upon. Foremost, governments had to flatten the curve of the number of the infected, stop the spread of the virus and make sure that care facilities would not be overwhelmed. Less or more intensive lockdown were on the list of measures taken by the governments around the world and led to negative, massive, micro and macroeconomic effects of the economy. These effects were immediately seen in the health system. The aim of this study is to find out how these acute challenges were managed, which were the biggest challenges for workforce and managers- from managing the personal protective equipment to facing the financial loss, and finally, propose solutions to contribute to improiving operations. Theoretical documentation at national and international level has been used to construct the study; identifying and analyzing the problems found on the basis of the information obtained by questionnaires; interpretation of results and drawing up the conclusion.
\end{abstract}

Keywords: health; measure; ressources; public health system; effects of the pandemic

\section{Introduction}

The objective of the study - Explore the perceptions of health care workers in relation to COVID-19 and the mode of information about COVID-19:
- Understand the knowledge, and perceptions of the health functionaries on COVID-19 and its transmission;

- Understand the Knowledge and practice gaps related to administering their work in response to COVID-19.

Cite this Article as: Ioana A. PADURARIU (2022)," Romania's Health Management in The Context of Covid-19", Journal of e-health Management, Vol. 2022 (2022), Article ID 489760, DOI: $10.5171 / 2022.489760$ 
- Determine their access and use of preventive measures and safety equipment while they handle patients and screening for COVID-19;

- Understand the degree of stress due to COVID-19;

-Identify the factors that shape decisionmaking and actions

The issue related to human resources is a topical one because the functioning of the activities of the state institutions depends on the quality of the people, and these aspects will be a continuous concern for both specialists and citizens.

The performance of institutions depends to a large extent on the professionalism of human resources, on the way they work with citizens and on the extent to which they assume responsibility for their work.

The human factor is the promoter of all the reforms that the public administration is going through, and its efficiency and effectiveness depend on this factor. Human resources play an important role in making institutional decisions, therefore it is easy to understand the increased attention paid to its positioning.

Human resources are limited and valuable, representing the most important investment in an institution, the results becoming obvious over time

\section{Theoretical framework}

\section{A Literature Review of the Human Resource Management}

Human resource management (HRM) is a modern, recent term for what has traditionally been called $<<$ personnel management $>>,<<$ management of personnel activities $>>,<<$ employee development $>>,<<$ industrial relations $>>$.

Bureaucratic models and the management of the functioning of the public sector are compared to discern the ways in which employment and organizational problems are conceptualized in each model. The new HRM models in the public sector have introduced the notion of human resources that is capable of achieving performance results, in accordance with the strategic direction of the public sector institution. (Sylvie; Serge, 1995).

The changing dimensions of public sector employment indicates that HRM has had a major impact on the functioning of the public sector. The HRM contributes significantly to understanding the constructive elements of the "new" public sector.

The role of the HR is crucial in building a culture of learning and adaptation, by creating values and appropriate behaviors in health workers (Anson 2000, Vestal, Fralicxn and Spreier, 1997).

A stronger emphasis on capital considerations and the elimination of rigid categories of work were some of the benefits of the shift from staff management to HRM in the public sector (Brown, 1997). The human resources manager, beyond the necessary and prior observance of the legal norms by all civil servants, refers to the quality and performance in the public service. HRM ultimately offers prospects to improve in the performance of civil servants' duties (eg efficiency), and the implementation of their rights and obligations (Collin, 1998).

While changes in the public sector over the past two decades have had a significant impact on the employees of public sector organizations, as well as the conditions in which people work, insufficient attention has been paid to the specific field of human resource management research and academic research about public sector (Cole, 2000).

Human resources are the most expensive and safest investmen that can be done by society in general and organizations in particular. Personnel investment guarantees the organization the survival and development; staff must be considered as a strategic capital (Stanciu, 2001).

Rondeau and Wagar (2002) found that hospitals that have adopted more 
progressive Management practices of human resources (HRM) reported efficiency improved, increased flexibility and a better reputation than hospitals that do not apply such practices.

HR practices trigger attitudes and responses to employed individuals, encouraging them to behave in ways consistent with the overall organizational performance targets. (West et al., 2002; Guest and collaborators, 2002; Purcell et al., 2003).

History shows us that humanity has often faced the epidemics. It has had more or less devastating consequences for the population. Smallpox, cholera, measles, tuberculosis and, in particular, the dreaded plague have repeatedly hit the world's population, having a strong impact on society, economy and political relations. (Hays, 2005)

Lack of advanced job-specific skills of HR professionals in the healthcare industry is one of the main reasons for the limitation in the scale or change of HR in health organizations (Khatri et al., 2006)

\section{Romania Health Situation}

The importance of human resources management, relative to the high or low level of performance of health care organizations has been ignored in the past. The medical sector reforms focused mainly on structural changes, cost control, the introduction and development of market mechanisms and increasing patient satisfaction.

Universal health coverage, regardless of socioeconomic status, geographic location, gender, age or pre-existing conditions, is more essential than ever (WHO, 2010)

Financing is the biggest problem of the Romanian health system Due to lack of know-how on major projects implementation In recent years, based on research in the field and experience in other sectors, the promotion of new and progressive HRM has been recognized as the solution to improving the performance of the health care system. A motivated and prepared workforce is a basic element for providing quality health services that fully meet patients' expectations

Adrian Wiener (2020) mentioned that financing itself is a problem. The fact that we have the lowest allocation in the EU (both per patient and as a percentage of GDP) is a problem. About the absorption capacity- even if we put 1 billion euros on the table now, the system could not absorb it.

There are two essential factors in the health system: infrastructure and health care system personnel. Romania has been facing a major crisis in terms of human resources in health for several years. Low income, poor working conditions, lack of equipment, reduced opportunities for professional development have been the main factors that caused this crisis.

1 in 4 Romanians has access to essential medical services, and $16.1 \%$ of Romanians in rural areas do not have a family doctor. Hospitals face a major shortage of staff. The average number of doctors and nurses in Romania, at 2.5 doctors per thousand inhabitants, is below the European average, which stands at 3.3 doctors per thousand inhabitants. In many counties in Romania the average is far below the national average.

Approximately 8,000 graduates are trained from the state budget each year, but many of them choose to leave the country to study abroad. Specifically, approximately 43,500 medical staff have expressed their intention to leave Romania, since 2007 until now. The fact that health professionals leave Romania only deepens the problems in the system

The motivation of medical staff to practice in Romania refers to the application of remuneration policies based on performance and results, granting facilities for practicing the profession in isolated areas, granting financial incentives in the form of bonuses and state guarantees, professional public recognition, in the context of affirming health as an essential social value for society. 
Human resource management in health is currently subject to the many challenges posed by the type of problems faced by other health systems from around the world, namely: lack of motivation of staff, its inefficient use, low productivity, inadequate training and, last but not least, poor distribution of its geographical location within the health system.

\section{Romania health system in pandemic context}

The motivation of the health professionals through bonuses were some of the main situations faced by the government, the management of the lack of doctors and nurses, the acquisition of newmedical equipment were some of the main situations faced by helth system.

Along with the risk that these health systems will be quickly overwhelmed by the coronavirus, there are travel restrictions that limit the ability of international staff to travel to different countries. Global pressure was also weighing on the production of certain medical resources, in particular personal protective equipment for healthcare professionals, including masks.

Health care organizations across all settings reported facing common challenges during COVID-19, including staffing issues, obtaining supplies, and implementing safety protocols and guidelines.

There was also a risk of shortage due to the lack of production of generic drugs and the difficulties of importing essential drugs (for example antibiotics and antiretrovirals) due to containment measures, reduction in the production of basic products, stopping exports, reallocation or storage of drugs and equipment for the coronavirus.

In this context of a pandemic, it was essential to maintain access to healthcare, both for patients with Covid-19 and for any other patient. This means ensuring that hospitals are not overwhelmed and that health workers can cope with the number of patients in need of intensive care, while continuing to provide treatment to other patients who also need it.

An unprecedented situation for which the health system was not prepared The medical system was blocked by the large number of infected patients, the illness of many medical staff and the lack of equipment.

\section{Methodology}

A cross sectional study was designed and data were collected using structured selfadministered questionnaires.

This cross-sectional study was carried out among health workers and included questions about the functioning of public health system during the pandemic. Data were collected during the period 2-10 February and were collected using a selfdesigned well-structured questionnaire. The questionnaire consists of three parts. Part 1 included profile of the participants, the second part covered the stress Management of health worker during pandemic and part 3 investigated problems faced by the workers and their attitude toward the irregularities in the system.

The respondents had the option of answering- 'Yes' or 'No'/'Agree'; 'Neither agree nor disagree' and 'Disagree'. Relative frequency (percentage) for categorical data was used.

\section{Results}

A total of 202 respondents completed the full questionnaire. Those with partially or incomplete answered responses were excluded. 
Table 1. Date of Survey

\begin{tabular}{|l|l|}
\hline Date of Survey: & Total \\
\hline 2-Feb-21 & 27 \\
\hline $3-$ Feb-21 & 34 \\
\hline 8-Feb-21 & 67 \\
\hline 9-Feb-21 & 11 \\
\hline $10-$ Feb-21 & 63 \\
\hline
\end{tabular}

Table 2. Profile of the responders

\begin{tabular}{|l|c|c|}
\hline $\begin{array}{c}\text { Profile of the } \\
\text { Health } \\
\text { professional } \\
\text { Interviewed }\end{array}$ & Total & $\%$ \\
\hline Specialist Doctor & 157 & $77.72 \%$ \\
\hline Nurse & 29 & $14.35 \%$ \\
\hline Lab Technician & 4 & $1.98 \%$ \\
\hline Vaccinator & 12 & $5.94 \%$ \\
\hline
\end{tabular}

Majority of the responders are doctors $(77,72 \%)$ and in total five type of health professionals were interviewed. 
Table 3. Stress Management

\begin{tabular}{|c|c|c|}
\hline $\begin{array}{l}\text { Stress Management of } \\
\text { health worker during } \\
\text { COVID-19: }\end{array}$ & YES & $\%$ \\
\hline $\begin{array}{l}\text { Are you sleeping less as } \\
\text { usual? }\end{array}$ & 182 & $90.09 \%$ \\
\hline $\begin{array}{lrr}\text { Would } & \text { you } & \text { consider } \\
\text { receiving } & \text { psychosocial } \\
\text { support? } & & \end{array}$ & 149 & $73,76 \%$ \\
\hline $\begin{array}{l}\text { Do you feel that you are } \\
\text { having excessive fear and } \\
\text { worry about your own } \\
\text { health and the health of your } \\
\text { loved ones? }\end{array}$ & 199 & $98.51 \%$ \\
\hline $\begin{array}{l}\text { After starting to work in } \\
\text { units where patients } \\
\text { diagnosed with COVID-19 } \\
\text { infection were hospitalized, } \\
\text { did you feel } \\
\text { avoided/rejected by the } \\
\text { persons with whom you } \\
\text { usually interact in daily life? }\end{array}$ & 194 & $96.03 \%$ \\
\hline $\begin{array}{l}\text { Are you feeling sadness, } \\
\text { anger, or frustration } \\
\text { because friends or loved } \\
\text { ones have unfounded fears } \\
\text { of contracting the disease } \\
\text { from contact with you } \\
\text { because of your work? (if } \\
\text { you answered yes to the } \\
\text { previous question) }\end{array}$ & 138 & $68.31 \%$ \\
\hline
\end{tabular}

Related to mental health and stress, majority of the health workers undergo stress in some degree or other. Three-fourth of them have reported poor appetite and sleep problems.
Almost $99 \%$ of the health workers responding to COVID have some degree of stress. Nearly $2 / 3 \mathrm{rd}$ of them have reported of stress from moderate to high or very high degree of stress due to COVID 19. 
Table 4. Administrative questions

\begin{tabular}{|c|c|c|c|c|}
\hline Administrative / management & Agree & \begin{tabular}{|l} 
Neither \\
agree nor \\
disagree
\end{tabular} & Disagree & Agree (\%) \\
\hline $\begin{array}{l}\text { Do you have Standard Operating } \\
\text { Procedure (SOPs) and policies } \\
\text { regarding COVID-19 at your } \\
\text { hospital? }\end{array}$ & 202 & 0 & 0 & $100 \%$ \\
\hline $\begin{array}{l}\text { Do you think all the employees of } \\
\text { your hospital should be tested for } \\
\text { COVID-19? }\end{array}$ & 202 & 0 & 0 & $100 \%$ \\
\hline $\begin{array}{l}\text { Is your hospital management } \\
\text { helpful to the employees in the } \\
\text { current crisis? }\end{array}$ & 166 & 12 & 24 & $82,17 \%$ \\
\hline $\begin{array}{l}\text { Is the availability of Personal } \\
\text { Protective Equipment (PPE) } \\
\text { adequate at your hospital? (PPE } \\
\text { include gowns, gloves, respirator } \\
\text { masks, eye protection) }\end{array}$ & 164 & 16 & 22 & $81.1 \%$ \\
\hline $\begin{array}{l}\text { Do you consider Romania health } \\
\text { care system was appropriately } \\
\text { prepared for this pandemic? }\end{array}$ & 11 & 46 & 145 & $5.44 \%$ \\
\hline $\begin{array}{l}\text { Are supported and helped enough by } \\
\text { the management? }\end{array}$ & 129 & 38 & 35 & $63.86 \%$ \\
\hline $\begin{array}{l}\text { Do you consider that the vaccination } \\
\text { plan is well developed? }\end{array}$ & 105 & 56 & 41 & $51.98 \%$ \\
\hline $\begin{array}{l}\text { Do you consider that the management } \\
\text { has made enough efforts to keep the } \\
\text { medical team at work? (due to the } \\
\text { increased illnesses of the medical staff) }\end{array}$ & \begin{tabular}{|l|}
97 \\
\end{tabular} & 23 & 82 & $48 \%$ \\
\hline
\end{tabular}

$166(82,17 \%)$ agree that the hospital management has been helpful during the current crisis, but also the less than half $(48 \%)$ consider that the management has not made enough efforts to keep the medical team at work.

These results indicate improvement of that administrative and managerial aspects over time.
The most relevant statement of this study "Romania health care system was appropriately prepared for this pandemic" recived 145 negatives answers meaning that the health system as well as the hospital management are far from handling such a fight properly.

\section{Table 5: The level of information received}

\begin{tabular}{|l|l|}
\hline \multicolumn{2}{|c|}{ Do you consider that you receive enough information about COVID-19? } \\
\hline Yes & $149(73.7 \%)$ \\
\hline No & $53(26.2 \%)$ \\
\hline & \\
\hline & Where do you get medical/scientific information about COVID-19? \\
\hline
\end{tabular}




\begin{tabular}{|l|l|}
\hline Medical journals & $179(88.6 \%)$ \\
\hline Scientific societies websites & $160(82.5 \%)$ \\
\hline Internal hospital protocols at workplace & $127(65.5 \%)$ \\
\hline Hospital protocols from other than workplace & $84(43.3 \%)$ \\
\hline Social media & $93(47.9 \%)$ \\
\hline Other & $12(5.9 \%)$ \\
\hline
\end{tabular}

\section{Conclusion}

Survey participants reported the most common changes resulting from COVID-19 included increased communication to keep staff updated on changes and to support their well-being, and changed plans to deal with staffing shortages.

I considered crucial to observe the current state of health situation in European countries, based on questionnaire.

Improving human resource management has its final result the increase in the quality of medical services to beneficiaries. All efforts of the management of the unit, in order to streamline the human resources management and general management, mainly aim to ensure patient satisfaction regarding the care provided.

The nursing profession must be made more attractive, with more responsibilities. This pandemic has shown us how much we need medical staff.

However, a health system does not work in isolation, but in a socio-economic and political context, as clearly illustrated by the direct and indirect effects of pandemics and other shocks to the health of vulnerable populations. A resilient healthcare system after COVID-19 will also need to address these vulnerabilities and inequalities and react in a sustainable way to all future crises.

People lacking appropriate health coverage have struggled to get tested and receive timely treatment for COVID-19 and other health emergencies. Countries must invest in universal health coverage, including expanding generics, consolidating medical purchases and fighting corruption.

To respond to the pandemic effectively and efficiently, and lay the foundations for a better future, governments must invest more in the essential functions of health systems, which are fundamental to maintaining and promoting health and wellbeing, which are "common goods for health".

\section{References}

- Cole, Gerald A. (2000). Managementul personalului. București: Codecs, 16-18

- Collin, P (1998). Dictionary of Human Resources and personnel management.

- Constantin, E. (2006) MANAGEMENT ÎN SISTEMUL DE SĂNĂTATE. Chișinău, Republica Moldova: Editura Epigraf, 57-60

- $\quad$ Enăchescu, D. 1994. Sănătate publică şi management sanitar, București Editura All

- Florian, B., \& T,oc, S. (2020). Policy note: Educația în timpul pandemiei . Răspunsuri la criza nesfârșită a sistemului educațional românesc. Bucureșt

- Kisely S, Warren N, McMahon L, Dalais C, Henry I, Siskind D. (2020). Occurrence, prevention, and management of the psychological effects of emerging virus outbreaks on healthcare workers: rapid review and meta-analysis.

[Online] https://doi.org/10.1136/bmj.m1642

- OECD/ European Observatory on Health Systems and Policies (2017), Romania: Profilul Sănătății în 2017 
[Online]. State of Health in the EU, OECD Publishing, Paris/European Observatory on Health Systems and Policies, Brussels. [Retrieved February 26, 2021]

http://dx.doi.org/10.1787/978926428 5392-ro

- Prompetchara, E.; Ketloy, C.; Palaga, T (20202). Immune responses in COVID19 and potential vaccines: Lessons learned from SARS and MERS epidemic. Asian Pac. J. Allergy Immunol. 5-8.

- de Simone, G.; Mancusi, C (2020). COVID-19-Timing is important. Eur., J. Intern. Med.., 124-127.

- $\quad$ Rondeau, K., 'Organizational Learning and Continuous Quality Improvement: Examining the Impact on Nursing Home Performance', [Online], Healthcare Management Forum, [Retrieved February 18, 2021], https://doi.org/10.1016/S08404704(10)60576-5

- Stanciu, S (2001), MANAGEMENTUL RESURSELOR UMANE Bucuresti: COMUNICARE.RO

- Trosa, S., Vallemont, S (1995). Moderniser l'administration : comment font les autres ?, Paris: Les Editions d'Organisation, 21-22

- WHO Headquarters (HQ), WHO Worldwide (2020), Coronavirus disease (COVID-19) outbreak: rights, roles and responsibilities of health workers, including key considerations for occupational safety and health. [Online]. World Health Organization and International Labour Organization. [Retrieved February 25, 2021],

- WHO/2019-nCoV/HCW_advice/2021.1

- World Health Organization (2020), Risk assessment and management of exposure of health care workers in the context of COVID-19. [Online]. Geneva. [Retrieved February 26, 2021] https://apps.who.int/iris/handle/106 65/331496

- World Health Organization (2020), Prevention, identification and management of health worker infection in the context of COVID-19. [Online]. Geneva. [Retrieved February 22], (https://www.who.int/publications/i/ item/10665- 336265, accessed 20 November 2020). 